\title{
Thirty-two cases of mesothelioma in Victoria, Australia: a retrospective survey related to occupational asbestos exposure
}

\author{
JAMES E. H. MILNE \\ Industrial Hygiene Division, State Health Department, 5 Parliament Place, Melbourne 3002 \\ Victoria, Australia
}

\begin{abstract}
Milne, J. E. H. (1976). British Journal of Industrial Medicine, 33, 115-122. Thirty-two cases of mesothelioma in Victoria, Australia: a retrospective survey related to occupational asbestos exposure. Mesotheliomas have been reported in four states in Australia. Crocidolite has been mined and milled at Wittenoom in West Australia where five cases of mesothelioma were reported after exposure of high intensity. The 32 cases of mesothelioma reported in this paper occurred during a period of 11 years in Victoria; 29 were pleural and three peritoneal. There were 22 autopsies. End occupations were misleading in $66 \%$ of cases. Two of the three subjects with peritoneal mesothelioma were siblings, and there was no evidence of occupational or other exposure to asbestos in either. There was a significant prevalence of pulmonary asbestos bodies in the tumour series as compared with an unselected consecutive series of 200 routine autopsies $(0.01>P>0.001)$. The occupational history was as effective a method of assessing 'true' asbestos exposure as the pulmonary asbestos body count. Five cases had had a duration of exposure of one year or less, but they had had heavy exposure. The latent interval before tumour development was 25 years or longer in each case. There was no known exposure to asbestos in five cases $(16 \%)$. The rare association of mesothelioma with types of asbestos other than crocidolite may not exist and could be explicable on the basis of the proportion (16\%) of these tumours arising randomly in the population.
\end{abstract}

Australia is a political federation comprising seven states, Victoria being the most densely populated (3.3 million) and most highly industrialized. Around the capital, Melbourne, which is a port with a population of 2 million, there has been rapid industrial development. Asbestos use and processing has markedly increased. Asbestos is not mined in Victoria. The crocidolite mine in West Australia is now closed, and open cut mining of chrysotile has only recently begun in New South Wales.

Mesotheliomata were regarded until recently as rare tumours.

There appears to be a clear relationship between the development of serosal tumours of both pleura and peritoneum and an earlier exposure to asbestos. Crocidolite has been noted to be peculiarly potent in this respect compared with other types of asbestos such as chrysotile, amosite, or anthophyllite (Gilson, 1973).

Of those occupationally exposed to asbestos only a small percentage develop mesothelioma; but not all mesotheliomata are related to asbestos exposure (Webster, 1972).

\section{Mesothelioma in other Australian states}

\section{West Australia}

At Wittenoom in the far north-west, crocidolite was 
mined underground until recently. Evidence from personal observation, from workmen's accounts, and from published investigations (McNulty, 1962; Major, 1968) indicates that exposure to asbestos was high both in the mine and the nearby milling plant, but not of long duration due to itinerant labour. Five cases of pleural mesothelioma have been reported, and McNulty (1972) noted that one case occurred after an elapsed time of only 13 years after eight months' exposure in the mill.

\section{New South Wales}

Barnes (1972) gave details of 13 cases of pulmonary malignancy and asbestosis, accepted by the Dust Diseases Medical Authority; pleural mesothelioma occurred in three.

\section{Queensland}

Mortimer and Campbell (1968) described two cases of pleural mesothelioma related to industrial asbestos exposure.

\section{Mesothelioma in Victoria}

Riddell (1966) reported three cases of pleural mesothelioma presenting at the Austin Hospital between 1962 and 1965. In 1967 an ongoing survey incorporating all cases diagnosed since 1962 was set up. In each case the diagnosis was confirmed independently by other pathologists and the occupational histories were to be personally assessed by the author. By the end of 1973, 29 cases of pleural mesothelioma had been investigated. Fifteen of these have been previously reported (Milne, 1969). There were three cases of peritoneal mesothelioma making a total of 32 .

\section{Source of case and findings}

A total of 23 cases presented at the Thoracic Unit of the Austin Hospital, Melbourne. The remaining nine cases were found at seven other institutions in Victoria. At the time of writing only one patient is alive. Autopsy has been carried out in 22. The diagnosis in the remaining 10 was made by pleural biopsy. Of the 10 biopsies, seven were made at thoracotomy and tissue macroscopically consistent with mesothelioma was seen.

The original diagnosis was not made in all cases by the same pathologist but all tissue sections have been seen by at least two pathologists who agreed that the diagnosis was mesothelioma. Sections from four cases have been sent to individual members of the UICC panel in England for opinion and in each case the diagnosis was confirmed.

\section{Assessment and grading of asbestos exposure}

Asbestos bodies

Histological sections of macroscopically normal lung parenchyma taken as a routine autopsy procedure were searched for asbestos bodies. Solitary fragments and granules were disregarded, and unless an unmistakably beaded body was seen it was not considered as a positive finding. 'Mature' bodies as described previously elsewhere (Milne, 1971), however, were included. Provided a clubbed head and a group of beads were seen the object was regarded as an asbestos body.

Some attempt at quantification was made, by categorizing subjects as follows:

Asbestos bodies in any one section

$\begin{array}{ll}\text { None } & \text { Not seen } \\ 1-3 & + \\ 4-10 & ++ \\ 11-20 & +++ \\ \text { More than 20 } & ++++\end{array}$

The writer assessed and counted the asbestos bodies. There were 21 cases where routine lung sections had been taken at autopsy. Of these, 11 showed asbestos bodies by light microscopy and four revealed asbestos bodies after digestion (Xipell and Bhathal, 1969). Thus asbestos bodies were seen in 15 out of 21 cases in which tissue was available for examination.

\section{Occupational history}

Evidence was obtained from the patient if possible, otherwise from relatives, friends, acquaintances, and medical records. According to the occupational history a category was ascribed as follows:

'Nil' No history of exposure. No likelihood of exposure.

'Possible' Patient had worked in an industry where asbestos could have been contacted.

'Probable' Patient had worked in an industry where asbestos was clearly known to have been used but where the patient's exact mode and duration of contact was unknown.

'Certain' Patient had worked in an industry where asbestos usage was established and where there was clear evidence that the patient had been in contact with the asbestos in the course of his work.

Thus (see Table 1) 14 subjects had 'certain' exposure to asbestos. No history of any sort of exposure could be elicited in five subjects; of these the writer was able to interview two and close relatives of the other three. No leading questions were asked at the outset but eventually these were introduced. Exposure to asbestos was categorically denied in all cases. The relatives claimed to have full awareness of the patient's working conditions. The two patients interviewed were rational and intelligent and gave sensible answers to questions. One had become an administrator but had worked as a carpenter with no exposure whatsoever to asbestos. The other gave her occupation as housewife; her only industrial experience had been in handling photographic chemicals and she firmly denied having been exposed to asbestos.

\section{Some illustrative case histories}

One common factor among those with certain history of asbestos exposure was the long delay or 'elapsed time' before development of mesothelioma after their exposure to asbestos had begun. Often the 
TABLE 1

Mesothelioma and Occupational Asbestos Exposure

\begin{tabular}{|c|c|c|c|c|c|c|c|}
\hline \multirow[t]{2}{*}{ Case } & \multirow[t]{2}{*}{$\operatorname{sex}$} & \multirow{2}{*}{$\begin{array}{l}\text { Asbestos } \\
\text { bodies }\end{array}$} & \multicolumn{3}{|c|}{ Exposure } & \multirow[t]{2}{*}{ Brief description of employment } & \multirow{2}{*}{$\begin{array}{l}\text { End } \\
\text { occupation }\end{array}$} \\
\hline & & & Past & Duration & $\begin{array}{l}\text { Estimated } \\
\text { intensity }\end{array}$ & & \\
\hline 1 & $\mathbf{M}$ & + & Probable & $1940-65$ & Mild & $\begin{array}{l}\text { Loaded packs of asbestos-bound weld- } \\
\text { ing rods }\end{array}$ & $\begin{array}{l}\text { Truck } \\
\text { driver }\end{array}$ \\
\hline 2 & $\mathbf{F}$ & ++++ & Certain & $1942-45$ & Heavy & Bound welding rods with crocidolite & $\begin{array}{l}\text { Invalid } \\
\text { pensioner }\end{array}$ \\
\hline 3 & $\mathbf{F}$ & No autopsy & Certain & $1942-47$ & Heavy & Bound welding rods with crocidolite & $\begin{array}{l}\text { Ledger } \\
\text { operator }\end{array}$ \\
\hline $\begin{array}{l}4 \\
5\end{array}$ & $\mathbf{F}$ & $\begin{array}{l}+++ \\
++++\end{array}$ & Certain & $1942-45$ & Heavy & Bound welding rods with crocidolite & Housewife \\
\hline $\begin{array}{l}5 \\
6\end{array}$ & $\begin{array}{l}\mathbf{M} \\
\mathbf{M}\end{array}$ & $\begin{array}{l}++++ \\
\text { No autopsy }\end{array}$ & $\begin{array}{l}\text { Certain } \\
\text { Probable }\end{array}$ & $\begin{array}{l}1935-50 \\
1939-68\end{array}$ & $\begin{array}{l}\text { Heavy } \\
\text { Heavy }\end{array}$ & $\begin{array}{l}\text { Bound welding rods with crocidolite } \\
\text { Exposed to dust from lagging, strip- } \\
\text { ping asbestos }\end{array}$ & $\begin{array}{l}\text { Foreman } \\
\text { Dockyard } \\
\text { worker }\end{array}$ \\
\hline 7 & $\mathbf{M}$ & $++t$ & Certain & $1942-68$ & Heavy & $\begin{array}{l}\text { Exposed to dust from lagging, strip- } \\
\text { ping asbestos }\end{array}$ & $\begin{array}{l}\text { Dockyard } \\
\text { worker }\end{array}$ \\
\hline 8 & $\mathbf{M}$ & No autopsy & Certain & $1930-45$ & Heavy & $\begin{array}{l}\text { Exposed to dust from lagging, strip- } \\
\text { ping asbestos }\end{array}$ & $\begin{array}{l}\text { Dockyard } \\
\text { worker }\end{array}$ \\
\hline 9 & $\mathbf{M}$ & $++t$ & Certain & 1930-42 & Heavy & $\begin{array}{l}\text { Exposed to dust from lagging, strip- } \\
\text { ping asbestos }\end{array}$ & Labourer \\
\hline 10 & $\mathbf{M}$ & ++ & Probable & 1943-44 & Heavy & $\begin{array}{l}\text { Exposed to dust from lagging, strip- } \\
\text { ping asbestos }\end{array}$ & $\begin{array}{l}\text { Dockyard } \\
\text { worker }\end{array}$ \\
\hline $\begin{array}{l}11 \\
12\end{array}$ & $\mathbf{M}$ & $\begin{array}{l}++ \\
\text { No autonsy }\end{array}$ & Certain & $1920-50$ & Heavy & Lagged steam pipes with asbestos & Barman \\
\hline 13 & $\mathbf{M}$ & No autopsy & Certain & $1942-43$ & Heavy & Sprayed insulation containing asbestos & $\begin{array}{l}X \text {-ray } \\
\text { crystallo- } \\
\text { grapher } \\
\text { Sewing } \\
\text { machine } \\
\text { mechanic }\end{array}$ \\
\hline 14 & $\mathbf{F}$ & ++ & Possible & $1941-45$ & Unknown & Munitions factory & $\begin{array}{l}\text { Tram con- } \\
\text { ductress }\end{array}$ \\
\hline $\begin{array}{l}15 \\
16\end{array}$ & $\begin{array}{l}\mathbf{M} \\
\mathbf{M}\end{array}$ & $\begin{array}{l}\text { No autopsy } \\
++\end{array}$ & $\begin{array}{l}\text { Possible } \\
\text { Probable }\end{array}$ & $\begin{array}{l}1910-? \\
1941-66\end{array}$ & $\begin{array}{l}\text { Unknown } \\
\text { Moderate }\end{array}$ & $\begin{array}{l}\text { Munitions factory } \\
\text { Welder in railway shop, near asbestos } \\
\text { mattresses }\end{array}$ & $\begin{array}{l}\text { Pensioner } \\
\text { Welder }\end{array}$ \\
\hline $\begin{array}{l}17 \\
18\end{array}$ & $\begin{array}{l}\mathbf{M} \\
\mathbf{F}\end{array}$ & $\begin{array}{l}\text { Not seen } \\
+ \text { Lung } \\
\text { digestion }\end{array}$ & $\begin{array}{l}\text { Possible } \\
\text { Nil }\end{array}$ & $\begin{array}{l}1925-30 \\
\text { Nil }\end{array}$ & $\begin{array}{l}\text { Mild } \\
\text { Nil }\end{array}$ & $\begin{array}{l}\text { Welder-loose asbestos lying about } \\
\text { Textile worker. Dressmaker }\end{array}$ & $\begin{array}{l}\text { Storeman } \\
\text { Dressmaker }\end{array}$ \\
\hline $\begin{array}{l}19 \\
20\end{array}$ & $\begin{array}{l}\mathrm{F} \\
\mathbf{M}\end{array}$ & $\begin{array}{l}\text { No autopsy } \\
+ \text { Lung } \\
\text { digestion }\end{array}$ & $\begin{array}{l}\text { Possible } \\
\text { Nil }\end{array}$ & $\begin{array}{l}1930 \\
\text { Nil }\end{array}$ & $\begin{array}{l}\text { Very mild } \\
\text { Nil }\end{array}$ & $\begin{array}{l}\text { Father worked in asbestos/cement } \\
\text { Carpenter, denied asbestos exposure }\end{array}$ & $\begin{array}{l}\text { Housewife } \\
\text { Manager }\end{array}$ \\
\hline 21 & $\mathbf{M}$ & Not seen & Possible & Uncertain & Very mild & Aircraft engineer & $\begin{array}{l}\text { Aircraft } \\
\text { engineer }\end{array}$ \\
\hline $\begin{array}{l}22 \\
23\end{array}$ & $\begin{array}{l}\mathbf{F} \\
\mathbf{M}\end{array}$ & $\begin{array}{l}\text { Not seen } \\
\text { No autopsy }\end{array}$ & $\begin{array}{l}\text { Nil } \\
\text { Certain }\end{array}$ & $\begin{array}{l}\text { Nil } \\
1938-39\end{array}$ & $\begin{array}{l}\text { Nil } \\
\text { Heavy }\end{array}$ & $\begin{array}{l}\text { Domestic servant } \\
\text { Insulator, spraying asbestos }\end{array}$ & $\begin{array}{l}\text { Housewife } \\
\text { Carpenter }\end{array}$ \\
\hline 24 & $\mathbf{M}$ & No autopsy & Certain & $1937-51$ & Heavy & $\begin{array}{l}\text { Welded railway trucks with asbestos- } \\
\text { bound electrodes }\end{array}$ & Pensioner \\
\hline 25 & $\mathbf{M}$ & No autopsy & Certain & 1936 & Heavy & $\begin{array}{l}\text { Swept asbestos and lagged as dock- } \\
\text { yard worker }\end{array}$ & Pensioner \\
\hline $\begin{array}{l}26 \\
27\end{array}$ & $\begin{array}{l}\mathbf{M} \\
\mathbf{M}\end{array}$ & $\begin{array}{l}\text { Not seen } \\
+ \text { Lung } \\
\text { digestion }\end{array}$ & $\begin{array}{l}\text { Possible } \\
\text { Probable }\end{array}$ & $\begin{array}{l}\text { Uncertain } \\
\text { Uncertain }\end{array}$ & $\begin{array}{l}\text { Uncertain } \\
\text { Heavy }\end{array}$ & $\begin{array}{l}\text { Fitter and turner } \\
\text { Worked in dockyards in Holland }\end{array}$ & $\begin{array}{l}\text { Pensioner } \\
\text { Carpenter }\end{array}$ \\
\hline 28 & $\mathbf{M}$ & Not seen & Nil & Nil & Nil & $\begin{array}{l}\text { Itinerant worker, then PMG for } 30 \\
\text { years }\end{array}$ & $\begin{array}{l}\text { Telephone } \\
\text { technician }\end{array}$ \\
\hline 29 & $\mathbf{M}$ & Not seen & Possible & $1920-?$ & Uncertain & Made asbestos gaskets as youth & $\begin{array}{l}\text { Chicken } \\
\text { farmer }\end{array}$ \\
\hline 30 & $\mathbf{M}$ & $+\begin{array}{l}\text { Lung } \\
\text { digestion }\end{array}$ & Certain & $1920-45$ & Moderate & $\begin{array}{l}\text { Boiler room attendant, stripping insu- } \\
\text { lation }\end{array}$ & Pensioner \\
\hline 31 & $\mathbf{F}$ & Alive & Nil & Nil & Nil & $\begin{array}{l}\text { Packed photographic chemicals } \\
\text { Denied asbestos exposure }\end{array}$ & Housewife \\
\hline 32 & $\mathbf{M}$ & ++++ & Certain & $1928-68$ & Heavy & Insulated, using asbestos in dockyards & $\begin{array}{l}\text { Process } \\
\text { worker }\end{array}$ \\
\hline
\end{tabular}




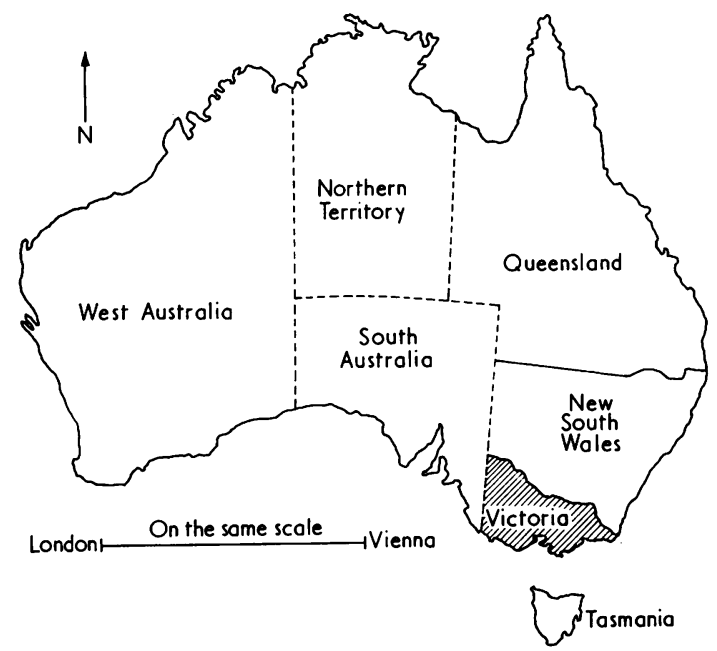

FIG. 1. Australia showing the seven states.

intensity of exposure was high although the duration was relatively short. Case 13 illustrates these points.

Case history no. 13

The patient was a sewing machine mechanic aged 44 years who also ran a small shop stocked with electrical goods. He had left school at the age of 14 years and had joined a firm engaged in acoustic insulating. For a year he had worked with this firm and his job had been to spray asbestos on to a wall previously coated with a black adhesive. The asbestos was supplied in large paper bags and was grey in colour. These bags were emptied by another man into a hopper feeding a garnetting machine which shredded the asbestos to an even consistency before feeding it to the spray gun. The patient wore a cartridge respirator with a felt filter and he recalled the profusion of the asbestos dust, which was such that invariably each day some of the dust escaped filtration and got into his nostrils as he sprayed. The patient suffered no further occupational dust exposure, having been a sewing machine mechanic ever since.

Such an occupational history provided firm evidence of asbestos exposure. In other cases the evidence was not at first clear but investigation enabled elucidation of a better picture, as in Cases 10 and 16.

\section{Case history no. 10}

When this man died, autopsy revealed a primary pleural tumour. There was some medical puzzlement that his exposure was said to have occurred when he had worked in the Railways Department only 10 years previously. The departmental records relating to time of exposure were good, because asbestos had been used in their workshops some 20 years before the man's death, and at that time the question of future development of pneumoconiosis had been raised. Further investigation of the patient's history, through interview of the widow, revealed that in 1943 (about 18 years before his death) he had started work in a naval dockyard where other information indicated that asbestos exposure was high. Thus the history of asbestos exposure was classed as 'probable' and related to his dockyard exposure, not to his more recent work in the Railways Department.

\section{Case history no. 16}

This man died in 1969, aged 66 years, having emigrated from England in 1966. The cause of death, at autopsy, was pleural mesothelioma. His occupation had been 'welder', and an occupational history was obtained from his wife and daughter. Details were sent to England for investigation by the Medical Inspector of Factories for the area in which he had worked.

It appeared he had been a rivetter and welder in railway workshops where lagging was carried out and asbestos mattresses and pre-formed sections were in use. It was said that he had had no direct contact with asbestos nor had he handled this in the course of his work. His history of asbestos exposure was classified as 'probable' and further search of the histological sections of lung parenchyma (where no asbestos bodies were seen by the pathologist) revealed at least six individual asbestos bodies in one section alone, tending to confirm the occupational classification.

\section{Peritoneal mesotheliomata}

There were three cases. One subject had worked on the docks and shipyards in Glasgow as a shipwright, and as an engine room insulator handling asbestos for about 40 years. The other two subjects, Cases 21 and 22, presented special features:

Case 21 A man aged 38 years when he died, whose occupation had been 'aircraft engineer'. Careful search of the lung tissue sections taken routinely at autopsy failed to reveal evidence of asbestos bodies. The diagnosis of peritoneal mesothelioma was made independently by three pathologists on the microscopic features. The macroscopic appearance of the tumour was one of intense widespread diffuse thickening of the peritoneum, which was regarded as characteristic. Interview of his wife (and later of an elder brother) revealed that he had been apprenticed as a turner and fitter. After apprenticeship he worked on aircraft engines. The highest rating which could be ascribed to his exposure to 
astestos was 'possible', and even this appeared doubtful.

Case 22 A woman aged 57 years when she died. The diagnosis of peritoneal mesothelioma had been made originally by the two pathologists who had seen most of the cases of pleural mesothelioma at the Austin Hospital. The woman had married again after the death of her first husband, and the change of name had concealed the fact that she was the elder sister of Case 21 who had died from a similar tumour. Her close relatives would not budge from the position that she had no occupation other than rural housework. There was no evidence of asbestos exposure. A brother gave the evidence on which the family tree (Fig. 2) is based. In this family of 10 there had been five deaths from malignancy. Two of these were caused by peritoneal mesothelioma, two by 'cancer of the stomach', and one by 'cancer in the lung'.

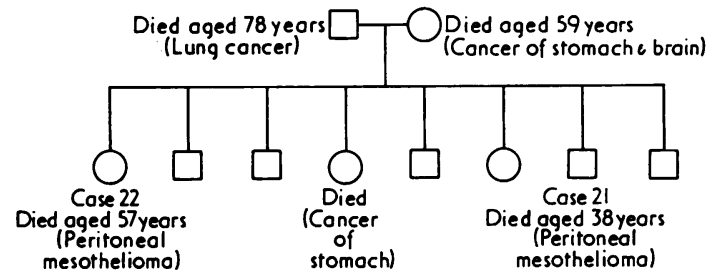

FIG. 2 Family tree of Cases 21 and 22 (details were provided by living siblings).

The brother was adamant that there had been no family exposure to asbestos. The father had been employed as a labourer, and later as an inspector with the Board of Works, engaged in maintenance of sewers. Any piping with which he had come into contact was of pottery construction. He had been a heavy smoker for many years.

The coincidence of two members of one family developing peritoneal mesothelioma without evidence of asbestos exposure is remarkable.

\section{End occupations}

'End occupation' is taken in this context to mean the occupation followed by the patient at the time of tumour diagnosis. In this series the 'end occupation' could have been misleading in at least 21 cases $(66 \%)$, (see Table 1). A typical example was Case 9, a 'labourer', formerly 'lemonade maker'. In fact this man had worked for 12 years before the second world war at the naval dockyard in Malta, exposed to high concentrations of asbestos dust. Case 11 had been a 'barman' for 15 years before his death but he had been a lagger for 30 years.

It is of some interest that Case 1 called himself 'truck-driver'; Case 2 'invalid pensioner'; Case 3 'ledger operator'; Case 4 'housewife'; Case 5 'fore- man'. These people were all shown to have worked at the same firm in the same room on the same process using South African crocidolite during a similar period of time. The firm's name had changed, the patients had lost contact with each other, and they did not know of the others' illness until they were admitted to hospital many years later.

Case 23 was a 'carpenter' but had been an asbestos sprayer in 1938 and 1939. Case 30 whose end occupation was 'retired pensioner' and who was said to have worked as an 'engine driver', had worked as a boiler room engineer and lagger for several years about 30 years previously.

\section{Discussion}

\section{Relationship to asbestos exposure}

Asbestos bodies The only estimate of the population prevalence of pulmonary asbestos bodies in Victoria is that of Xipell and Bhathal (1969). In an unselected consecutive series of 200 autopsies, using a digestion technique, they found asbestos bodies in 87 cases (Table 2). The same digestion technique was

TABLE 2

Asbestos Bodies in Two Series of AutOPsies

\begin{tabular}{|c|c|c|c|c|}
\hline \multicolumn{2}{|l|}{ Autopsy } & \multicolumn{2}{|c|}{ Asbestos bodies } & \multirow[t]{2}{*}{ Total } \\
\hline & & Seen & Not seen & \\
\hline $\begin{array}{l}\text { Routine .. } \\
\text { Mesothelioma }\end{array}$ & $\begin{array}{l}\ldots \\
\ldots\end{array}$ & $\begin{array}{l}87 \\
15\end{array}$ & $\begin{array}{r}113 \\
6\end{array}$ & $\begin{array}{r}200 \\
21\end{array}$ \\
\hline Total & . & 102 & 119 & 221 \\
\hline
\end{tabular}

$x^{2}=7 \cdot 14$ One degree of freedom $P<0.01$.

used to reveal asbestos bodies in four cases in our series in which asbestos bodies were not easily seen by light microscopy. Asbestos bodies were found in 15 out of 21 autopsied cases in the present series. The difference is significant at the $1 \%$ level (see Table 2 ).

The two familial cases of peritoneal mesothelioma did not produce any evidence of asbestos bodies.

Of the 10 cases on whom autopsy was not performed, seven were considered to have certainly been exposed to asbestos, one probably exposed, and two possibly exposed.

There was no evidence of occupational asbestos exposure in one case in which the subject's father had worked for a short time in an asbestos/cement factory many years previously. On the basis of the 'neighbourhood cases' noted by Newhouse and Thompson (1965), she was allotted a category of 'possible'.

Occupational history Considering the total group 
of 32 patients, there were 27 patients about whom some possible history of exposure to asbestos could be elicited. Thus there were two parameters, namely: exposure history

the finding of asbestos bodies

as pointers to the 'true incidence' of asbestos exposure.

Comparing the two, the value of $\chi^{2}$ was 0.62 which indicated no significant difference between them as indicators of 'true' asbestos exposure $0.5>$ $\mathbf{P}>\mathbf{0 . 3}$.

\section{Type of asbestos exposure}

It has not been possible to analyse the series according to the type of asbestos exposure. Crocidolite is said to have an enhanced carcinogenic effect as compared with other forms of asbestos, but there was no way of testing this hypothesis quantitatively in our series since most patients suffered a mixed exposure. A small subgroup who shared a common source of exposure, however, were exposed solely to imported crocidolite ('Cape blue' asbestos). These were Cases 1 to 5 and they were all employed in the manufacture of welding electrodes of the earliest type, in which asbestos string was wound around the coated iron electrodes giving rise to clouds of blue asbestos dust. The earliest date at which exposure began was 1935. Three of the five in the subgroup were women engaged on a temporary basis during the war; their exposure ceased about 1945. Thus their exposure to crocidolite was of short duration but of high intensity. There was an elapsed time of at least 20 years between start of exposure and development of mesothelioma in all five. McNulty's case, mentioned previously, was of similar exposure pattern (high intensity and short duration) and the development of a mesothelioma followed only 13 years later. This may be related to the fact that Australian crocidolite consists of very fine fibres. The susceptibility of Australian workers to both local and imported crocidolite has been clearly demonstrated and in Victoria some neoplastic outcome of the West Australian conditions may be revealed in the future as itinerant workmen move from state to state.

Duration of exposure, elapsed time, and latent interval The exposures as listed show a range of duration from six months to nearly 30 years. One envisages a product relationship between duration of exposure and intensity (US Public Health Service Report, 1972) to give an index indicative of total number of fibres inhaled and some measure of carcinogenic effect. When a critical 'dose level' has been reached, a response may be stimulated (for example, mesothelioma) which requires a latent interval of many years to manifest itself.

With exposures of long duration, which cease only on the eventual diagnosis of mesothelioma, one has no idea when the critical level of exposure might have been sufficient to induce carcinogenesis. In Case 1, for example, this would be impossible to establish because exposure was continual from 1940 to 1965 . Therefore 'elapsed time' as estimated in such cases, gives no indication of the latent interval between dose and response.

A more accurate estimate of the latent interval can be made with short well-delineated exposures. In the series there were five cases, all male, for whom the duration of exposure was a year at the most, and whose exposure began about 25 years or earlier before tumour development. Probably the most reliable witness was Case 12 , an $x$-ray crystallographer, who understood the importance of accuracy in giving his occupational history. He gave firm evidence that the duration of his exposure was only six months in 1942. This indicates a latent interval of 25 years, after heavy exposures to asbestos imported into Australia.

The reported West Australian case suggests that for the finer Australian crocidolite with heavy exposures of short duration, the latent interval before mesothelial tumour development could be even less. That we in Victoria are now seeing the results of the industrial conditions of about 30 years ago is shown by the fact that no case in our series began exposure after 1943.

\section{Occupational groups}

The occupations involved showed a similarity to those seen in larger series investigated in other countries. Of 27 subjects with a history of possible exposure, occupationally, to asbestos, eight had worked in dockyards, five had worked binding crocidolite string on to welding rods, and three were welders. Other occupations involved were lagging, asbestos spraying, and asbestos carding.

\section{Mesothelioma with no exposure to asbestos}

One of the features of most series of carefully investigated cases of mesothelioma is the presence of those whose past history, either occupational or domestic, does not include exposure to asbestos. Webster (1972) noted that the South African Asbestos Tumour Reference Panel had registered 179 cases of pleural mesothelioma by the end of 1969 . The environmental history was known in 148 cases and $24(16 \%)$ of these showed no evidence of asbestos exposure. McDonald et al. (1970) studied all fatal malignant mesothelial tumours known to pathologists in Canada 'between 1959 and mid1968'. Using a technique of obtaining occupational histories 'blind', only $20 \%$ of male cases and one female case were demonstrated to have had occupational exposure to asbestos. Greenberg and Lloyd Davies (1974) investigated 413 notifications of meso- 
thelioma in the United Kingdom and accepted 246 cases as definite, of which, in 38 cases $(15 \%)$ there was no history of any exposure to asbestos after careful inquiry.

Of the 32 cases in this Australian series five $(16 \%)$ were devoid of evidence which might indicate a link with asbestos. The numbers are much less than in the South African and English series but the percentages are very similar. In neither series was a 'blind' technique used. In our series in spite of direct questioning, patients and close relatives remained unmoved in their denial of exposure to asbestos.

It seems clear that some mesothelial tumours (at least $15 \%$ are unrelated to asbestos exposure. Furthermore in the present climate of opinion some subjects could mistakenly be categorized as having a possible exposure (or even probable exposure) to asbestos, because of its widespread use, and Case 19 in our series may be one such. Given intensive interrogation, a large proportion of any industrial population might 'confess' to asbestos exposure. This may explain the discrepancy between McDonald's results and those of other workers.

Webster (1965) pointed out that mesotheliomata occur in families, and although many workers have been exposed few have ultimately developed the tumour. These two factors indicate that there is some predisposition to serosal tumour formation in certain individuals, sometimes exhibited as a familial trait. The occurrence of two cases of peritoneal mesothelioma in one family, neither of whom could be regarded as having significant asbestos exposure, lends support to this view.

The presence, in our series, of five cases $(16 \%)$ lacking evidence of exposure to asbestos also lends credence to the theory that mesotheliomata have been in existence in larger numbers in the community than we had been aware. The search for these tumours has become intense of latter years, and consequently recognition has probably been facilitated. Moreover a further point comes out of this in relation to the type of asbestos causing mesothelioma. There is evidence linking crocidolite exposure with the later development of mesothelioma. Other types of asbestos, for example, chrysotile, rarely induce mesothelioma. Perhaps this rarity does not exist in fact. If at least $15 \%$ of all known mesotheliomata are unrelated to asbestos and occur 'spontaneously' for no obvious reasons, there exists the possibility that such tumours may also randomly but rarely occur in a population of workers exposed to chrysotile, particularly a large population; so that the coincidence of two factors in time and place may have given rise to an erroneous idea of cause and effect.

\section{Conclusions}

This small series provides confirmatory evidence that in Victoria, as elsewhere in the world, there is a relationship between occupational exposure to asbestos and the subsequent development of a mesothelial tumour, after an elapsed time of the order of 20 years. Exposure times in five cases were of less than one year's duration but these were of high intensity.

'End occupations' bear little relationship to past occupational exposure. The occupational history is equally effective as an asbestos body count to indicate past exposure to asbestos. The most common occupation in the series was 'dockyard employee'.

In five of the cases $(16 \%)$ there was no evidence of exposure to asbestos, despite intensive investigation. This figure is similar to that found in other larger series. It indicates that mesotheliomata do occur unrelated to asbestos exposure, possibly in larger numbers than previously suspected, and may serve to show that the so-called rare association of mesothelial tumours with types of asbestos other than crocidolite, is in fact non-existent.

Two cases of peritoneal mesothelioma in siblings who had no history of asbestos exposure probably represent a remarkable coincidence of familial cancer incidence.

My gratitude is expressed to the following who have assisted with this paper: Professor H. Attwood, Dr A. J. Christophers, Dr J. Riddell, Dr J. Ireton, Dr A. Parkin, Dr G. Price, Dr J. Clarebrough, Dr A. Campbell and members of the staff of the Austin Hospital Thoracic Unit, Dr R. Motteram, Dr R. Doig, Dr J. Hicks, Dr S. Pilbeam, and Dr A. Jackson. Mrs M. Griffiths has typed many drafts; Dr B. McCloskey, Chief Health Officer, has given permission to publish the paper.

\section{References}

Barnes, R. (1972). Asbestos and malignant disease. Medical Journal of Australia, 2, 1107-1112.

Gilson, J. (1973). Asbestos cancer: past and future hazards. Proceedings of the Royal Society of Medicine, 66, 395-403.

Greenberg, M. and Lloyd Davies, T. A. (1974). Mesothelioma register 1967-68. British Journal of Industrial Medicine, 31, 91-104.

McDonald, A., Harper, A., El Attar, O., and McDonald, J. (1970). Epidemiology of primary malignant tumours in Canada. Cancer, 26, 914-919.

McNulty, J. C. (1962). Malignant pleural mesothelioma in an asbestos worker. Medical Journal of Austratia, 2, 953-954.

- (1972). Personal communication.

Major, G. (1968). Asbestos dust exposure. In Proceedings of the First Australian Pneumoconiosis Conference, p. 467. Australian Health Department.

Milne, J. E. H. (1969). Fifteen cases of mesothelioma associated with occupational exposure to asbestos. Medical Journal of Australia, 2, 669-673. 
(1971). Developmental changes in asbestos bodies and their significance. Transactions of Society of Occupational Medicine, 21, 118-121.

Mortimer, R. and Campbell, C. (1968). Asbestos exposure and pleural mesotheliomata. Medical Journal of Australia, 2, 720-722.

Newhouse, M. L. and Thompson, H. (1965). Mesothelioma of pleural and peritoneum following exposure to asbestos in the London area. British Journal of Industrial Medicine, 22, 261-269.

Riddell, J. (1966). Three cases of mesothelioma. Medical Journal of Australia, 2, 554-558.

US Public Health Service Report (1972). Occupational exposure to asbestos-criteria for a recommended standard, Sect. V, pp. 12-13, National Institute for Occupational Safety and Health. US Department of Health, Education, and Welfare, Washington, DC.

Webster, I. (1965). Biological effects of asbestos. Sect. IX. Mesotheliomatous tumours in South Africa. Annals of the New York Academy of Sciences, 32, 1-766.

(1972). The pathology of asbestosis. In Medicine in the Mining Industries, edited by J. Rogan, chap. 111, pp. 39-55. Heinemann, London.

Xipell, J. and Bhathal, P. (1969). Asbestos bodies in lung: an Australian report. Pathology, 1, 327-330.

Received for publication 16 June 1975

Accepted for publication 19 January 1976

\section{The February (1976) Issue}

Myocardial infarction in car assembly workers P. J. Baxter, W. G. White, C. F. B. Sanderson, G. M. Barnes, C. S. Baxter, and R. M. Acheson

Absence attributed to sickness in oil tanker crews J. T. Carter

Significance of irregular small opacities in radiographs of coalminers in the USA H. E. Amandus, N. L. Lapp, G. Jacobson, and R. B. Reger

Follow-up of ventilatory lung function in a group of cement workers M. Šarić, I. Kalačić, and A. Holetić

Induction of fibrogenesis by lung antibody-treated macrophages $\quad$ D. M. Lewis and R. Burrell

Biochemical changes during the initial stages of industrial lead exposure G. I. Benson, W. H. S. George, M. H. Litchfield, and D. J. Seaborn

Activity of erythrocyte $\delta$-aminolevulinic acid dehydrase and its change by heat treatment as indices of lead exposure $M$. Chiba

Plasma concentrations of the oxime Pralidoxime Mesylate (P2S) after repeated oral and intramuscular administration P. Holland and D. C. Parkes

Notes and miscellanea

Are glass fibres carcinogenic to man? A critical appraisal J. Milne

Book review

Information section

A number of copies are still available and may be obtained from the Publishing Manager, British Medical Association, Tavistock Square, London WC1H 9JR, price $£ 2.50$ (U.S.A. \$7.50). 